\title{
Project Quality Management Performance: An Insight to Sustainable Development Initiatives in Oil and Gas Host Communities
}

\author{
Prince Destiny Ugo ${ }^{1}$ \\ ${ }^{1}$ University of Port Harcourt, Nigeria \\ Correspondence: Prince Destiny Ugo, University of Port Harcourt, Nigeria. E-mail: prince_ugo@uniport.edu.ng
}

Received: September 14, 2017 Accepted: October 5, 2017 Online Published: October 25, 2017

doi:10.5539/jms.v7n4p76 URL: http://doi.org/10.5539/jms.v7n4p76

\begin{abstract}
A fundamental principle of project quality management is that quality is planned into project and not inspected through project. In the context of host communities in developing countries with mineral exploration activities construction projects and contracts generally is a key provider of employment in both short, medium and long term and particularly for the locals, therefore the incorporation of quality management systems in project life cycle is paramount for sustainable development. Ensuring project quality plays an important role in socio-economic development of people as it provides the most basic infrastructure that promotes economic activities. Quality management systems (QMS) has significant value relating to project quality and cost reduction and a comprehensive quality management culture can promote project success, mutual beneficial relationship and organisational sustainability. This study provides empirical findings emanating from local vendor(s) understanding, compliance and implementation of quality management systems in a multinational oil company (MNOC) community assisted projects. The study utilised SPSS version 22 for the statistical data analysis and Goodness-of-fit-test interrogated the assumption that contractors are not complying with quality management systems in project execution. The study found inter alia that $65 \%$ of the vendors are registered as closed corporation (sole proprietorship), $15 \%$ were limited liability companies, while $20 \%$ belong to other category such as subcontractors. Furthermore, $98 \%$ of the 222 respondent are yet to develop a quality manual and a conceptual nominated vendor system (NVS) project quality model was developed to improve the contract award and project management status quo, with emphasis on the need for integration of quality management systems in project life cycle for the oil and gas host communities.
\end{abstract}

Keywords: sustainable development, host communities, niger delta, nominated vendor system model, project quality management, quality management systems

\section{Introduction}

Most project participants have adopted different management practices for project execution targeted exclusively towards completion and commissioning without developing, managing and implementing quality management systems (QMS) (Othman, 2011, pp. 31-54; Ahmed, Aoieon, Tang, \& Zheng, 2005, pp. 149-161; Xiao \& Proverb, 2002, pp. 672-687) from the project initiation phase that will guide the development of clients' objectives towards improved service quality, faster project execution and innovations (Andrew \& Lau-Tang, 2009, pp. 410-425; Low \& Teo, 2004, pp. 8-15) and the quality management practices are designed to meet clients' views of quality, as well as, complying with specifications (Tang, Poon, Ahmed, \& Wong, 2003; Tang, Ahmed, Aoieong, \& Poon, 2005). Construction projects and contracts generally is a key provider of employment in both short, medium and long term and particularly in oil and gas host communities, therefore the incorporation of quality management systems in project life cycle is paramount for sustainable development.

Multinational oil companies (MNOC) has supported a number of community projects and entrepreneurship programs of various scale and design in their respective host communities in the Niger Delta of Nigeria; However, inter alia memorandum of understanding (MOU) and agreements has severely been neglected in most instances by some of the companies which has resulted in community protest leading to shutting down of oil and gas production facilities. In Egi host communities in Rivers State Niger Delta as contained in an agreement between Total Exploration and Production Nigeria (TEPNG) and Egi oil and gas landlord families, the host communities refers to communities such as Obagi, Ogbogu, Oboburu, Akabuka, Obite, Erema, Obiyebe, Akabta and Egita all in Ogba/Egbama/Ndoni Local Government Area of Rivers State (TEPNG \& Landlords, 2012). However unlike in the past, this current agreement, implementation and monitoring structures has brought 
relative peace in Egi Kingdom; it is also noteworthy that socio-economic engagement between the host communities and TEPNG including their vendors has also been sporadic and characterised by gross neglect for community project quality by some local vendors; thus contractors are not held accountable for poor quality projects by their respective communities including deviation from specifications; and this has led to unaccounted community funds, project failure and over budgeting in projects as in the case of Obite community where a community guest house project has been funded annually by TEPNG, yet remained uncompleted year-on-year, partly due to deviations from the original specification and insufficient knowledge of project quality management structures by some of the contractors, this trends can be linked to inter alia nomination of contractor(s) (Figure 1) which are mostly awarded on the grounds that vendors are indigenous or in the community leadership. These processes particular in Obite community that host the Liquefied Natural Gas (LNG) plant remains unabated, entrenched and normalised. Thus, leaving the entire Obite community in project quagmire and resource platykurtosis. In this paper the author developed a nominated vendor system (NVS) project quality model presented in (figure 2) and findings were based on the level of compliance to quality standards and project specifications from a quality management perspective; and recommendations were proffered on improving project quality in host communities in the area under research.

Quality management systems (QMS) has significant value relating to good project quality and cost reduction (Hiyassat, 2000, pp. 275-280; Holm, 2000, pp. 527-540) and a comprehensive quality management culture can promote project success, mutual beneficial relationship and organisational sustainability (Ogwueleka, 2011, pp. 343-349). Quality management principles and tools are critical requirements in project management practice (Hoxley, 2000, pp. 599-605; KimWanSiu, Bridge, \& Skitmore, 2001, pp. 719-726) to comprehensively accommodate the variability in project execution, and may result in frequent variation requisition (Aiyetan, 2014, pp. 755-769) when it is not institutionalised. In the context of this study, the author defines nominated vendor system (NVS) as a contract awarding system in host community agreement-based projects that provide a concise project quality management model for stakeholders in contract award and project management. While the NVS may be a partial solution to growing trends of project failure and scope variations in host communities, it serves as a conceptual framework for project donors and promotes stakeholders taking responsibility for the execution of projects in their respective domain.

The model thus acknowledges the paramount need for beneficiaries of the contract nomination award process to establish an integrated quality management systems as a core foundation for project quality and sustainable development. A project completion should however not warrant the issuance of a job completion certificate and subsequent commissioning of the project by donors, thus the fact that a project is seen as completed onsite, does not necessarily constitute a quality project. It is a continuous process that should have started and end with the project. In the light of this, the study accessed the understanding, development and implementation of project quality management systems (PQMS) in the execution of community projects in some host communities in Niger Delta, Nigeria; because regardless of the clamour for resource control, marginalisation and consequent insecurity in the Niger Delta oil and gas sector; there are also significant infrastructural and human capital development in the region and Nigeria in general, but adherence to quality management principles is conspicuously lacking in most instances that results in project failure and specification variations. The word vendors and contractors are interchangeably used in this study.

\subsection{Host Communities Project Award Status Quo}

The oil and gas host communities in Egi kingdom has MOU and agreement with TEPENG (TEPNG \& Landlords, 2012) that made provision for "Development envelope" also known as envelope money (Table 1), which is an amount of money allocated for the purpose of socio-economic and infrastructural development of host families and communities; in distributing the envelope money, projects are nominated by the communities and the names of companies or person(s) to execute the project are also nominated. Thereafter, TEPNG will share the job among the nominees within the allocated budget for each community. The challenge with this procedure is that:

1) The process does not promote competitive tendering that allow TEPNG to select preferred bidders based on competence.

2) It does not provide a platform to access constructability which is referred to as a project management technique that involves the integration of construction knowledge and experience in planning, procurement, engineering management and field operations in project execution (Connor \& Tucker, 1986, pp. 281-290; Pocock, Kuennen, Gambatese, \& Rauschkolb, 2006, pp. 373-383; IPENZ, 2008; Saghatforoush et al., 2009, pp. 518-532; Radosavljevic \& Bennett, 2012) that entails optimisation of different project constraints in meeting the 
primary objectives (Trigunarsyah, 2004, pp. 567-580; Arditi, Elhassan, \& Toklu, 2002, pp. 117-126; Jergeas \& Vander-Put, 2001, pp. 281-290).

3) The nomination process does not also promote adherence to statutory project quality and specification, and consequently quality and reliability may be compromised.

This study is about improving project quality and quality management systems in oil and gas host communities in Egi kingdom; other issues such as constructability, tendering processes, and adherence to statutory regulations are not within the ambit of this research; therefore are excluded. In the light of the aforementioned project award status, the author investigated the following research questions:

1) What is the level of quality management awareness of local vendors in Egi host communities?

2) How does vendors in Egi host communities implement project quality management systems in community projects? and

3) To what extent does local vendors in Egi host communities comply with quality standards?

Table 1. Envelope money for Egi host communities

\begin{tabular}{lllllll}
\hline S/No & Host communities & \multicolumn{5}{l}{ Development Envelope in (million) Nigeria Naira per year } \\
& & $\mathbf{2 0 1 2}$ & $\mathbf{2 0 1 3}$ & $\mathbf{2 0 1 4}$ & $\mathbf{2 0 1 5}$ & $\mathbf{2 0 1 6}$ \\
\hline 1 & Obagi & $\mathrm{N} 98.75 \mathrm{~m}$ & $\mathrm{~N} 100 \mathrm{~m}$ & $\mathrm{~N} 100 \mathrm{~m}$ & $\mathrm{~N} 100 \mathrm{~m}$ & $\mathrm{~N} 100 \mathrm{~m}$ \\
2 & Ogbogu & $\mathrm{N} 98.75 \mathrm{~m}$ & $\mathrm{~N} 100 \mathrm{~m}$ & $\mathrm{~N} 100 \mathrm{~m}$ & $\mathrm{~N} 100 \mathrm{~m}$ & $\mathrm{~N} 100 \mathrm{~m}$ \\
3 & Oboburu & $\mathrm{N} 68.75 \mathrm{~m}$ & $\mathrm{~N} 70 \mathrm{~m}$ & $\mathrm{~N} 70 \mathrm{~m}$ & $\mathrm{~N} 70 \mathrm{~m}$ & $\mathrm{~N} 70 \mathrm{~m}$ \\
4 & Akabuka & $\mathrm{N} 68.75 \mathrm{~m}$ & $\mathrm{~N} 70 \mathrm{~m}$ & $\mathrm{~N} 70 \mathrm{~m}$ & $\mathrm{~N} 70 \mathrm{~m}$ & $\mathrm{~N} 70 \mathrm{~m}$ \\
5 & Obite & $\mathrm{N} 68.75 \mathrm{~m}$ & $\mathrm{~N} 70 \mathrm{~m}$ & $\mathrm{~N} 70 \mathrm{~m}$ & $\mathrm{~N} 70 \mathrm{~m}$ & $\mathrm{~N} 70 \mathrm{~m}$ \\
6 & Erema & $\mathrm{N} 30 \mathrm{~m}$ & $\mathrm{~N} 32 \mathrm{~m}$ & $\mathrm{~N} 32 \mathrm{~m}$ & $\mathrm{~N} 32 \mathrm{~m}$ & $\mathrm{~N} 32 \mathrm{~m}$ \\
7 & Obiyebe & $\mathrm{N} 23 \mathrm{~m}$ & $\mathrm{~N} 25 \mathrm{~m}$ & $\mathrm{~N} 25 \mathrm{~m}$ & $\mathrm{~N} 25 \mathrm{~m}$ & $\mathrm{~N} 25 \mathrm{~m}$ \\
8 & Akabta & $\mathrm{N} 7.50 \mathrm{~m}$ & $\mathrm{~N} 8 \mathrm{~m}$ & $\mathrm{~N} 8 \mathrm{~m}$ & $\mathrm{~N} 8 \mathrm{~m}$ & $\mathrm{~N} 8 \mathrm{~m}$ \\
9 & Egita & $\mathrm{N} 12 \mathrm{~m}$ & $\mathrm{~N} 15 \mathrm{~m}$ & $\mathrm{~N} 15 \mathrm{~m}$ & $\mathrm{~N} 15 \mathrm{~m}$ & $\mathrm{~N} 15 \mathrm{~m}$ \\
\hline Total amount per year combined & $\mathbf{N 4 7 6 . 2 5 m}$ & $\mathbf{N 4 9 0 m}$ & $\mathbf{N 4 9 0 m}$ & $\mathbf{N 4 9 0 m}$ & $\mathbf{N 4 9 0 m}$ \\
\hline
\end{tabular}

Source: (TEPENG \& Landlords, 2012).

In order to address the stated questions, research objectives were provided that seeks:

1) To establish the level of awareness of local vendors, with regards to project quality management systems;

2) To find out whether or not the vendors are implementing quality management systems in project execution; and

3) To also determine compliance level of quality standards by local vendors in Egi host communities. 


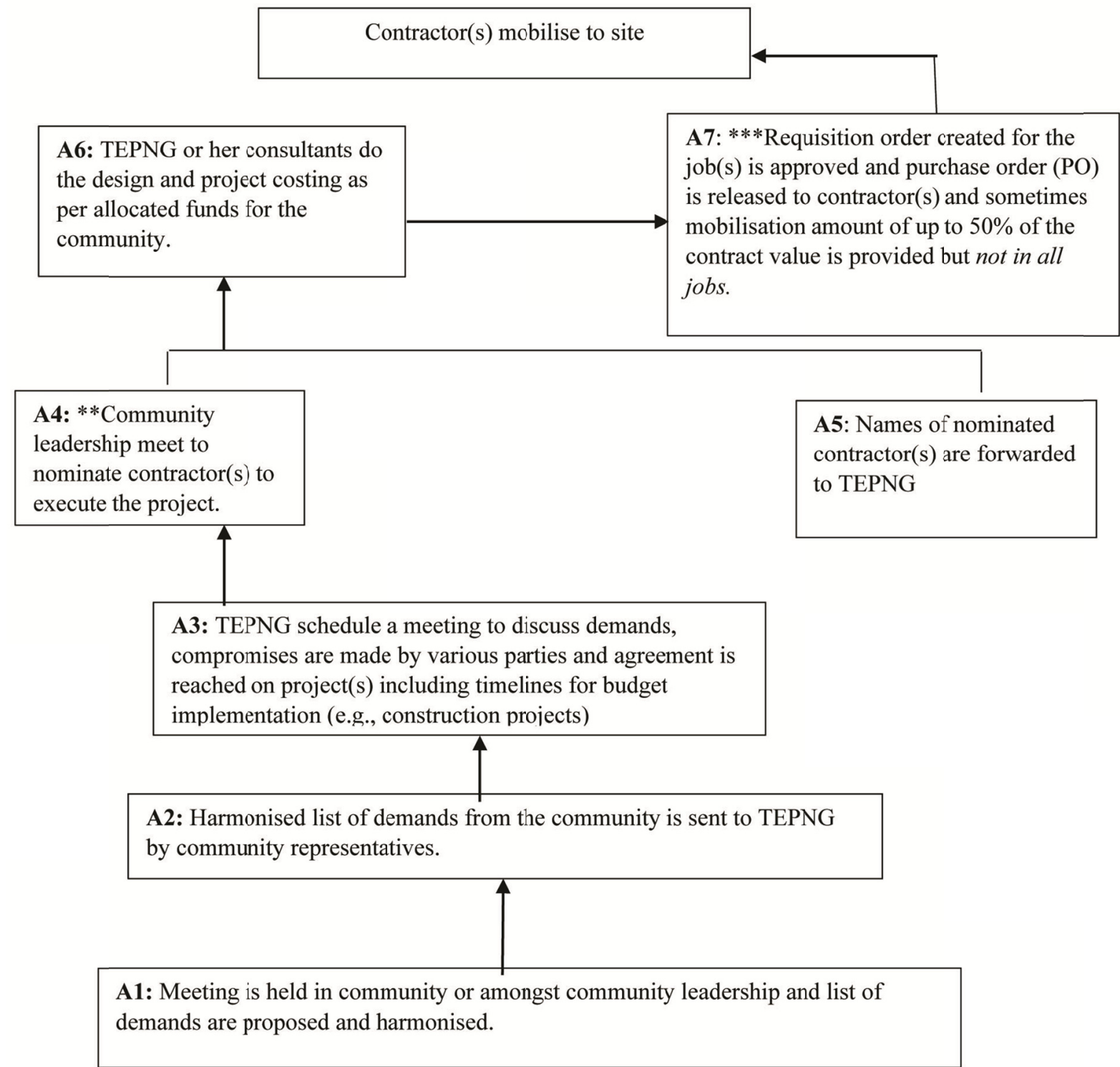

Figure 1. Nomination of contractors' and contract award procedures in oil and gas host communities

Source: Author's field survey 2015.

Note. ** The community leadership in this context are usually made up of the traditional rulers, chiefs, members of the Community Development Committee (CDC), although these structures varies from each communities. Depending on the community structure sometimes any person deemed as elite either by virtue of class (with political or economic resources) including the level of academic prowess and influence in the society could become part of the community leadership, and in some cases the youth associations leaders and the women group leaders also forms part of the leadership that decides project(s). The list of contract(s) that often originates amongst these community leaders are thereafter sent to the company and the project amount allocated to the community for the year are distributed in various Purchase Order (PO) accordingly. *** It is important to note that the procedures presented in figure 1 does not in any way represent TEPNG's contract award processes, it only highlight the processes followed when contractors are "nominated by the host communities".

\section{Research Hypothesis}

Within the scope of this study, the following hypothesis were formulated to guide the research:

\section{Hypothesis}

$\mathrm{H}_{0}$ : There are compliance of quality management systems in project execution among contractors in Egi host communities.

$\mathrm{H}_{\mathrm{a}}$ : There are non-compliance of quality management systems in project execution among contractors in Egi host communities. 


\section{Literature Review}

\subsection{Introduction}

In recent past, quality management has gradually appeared in the construction reliability and project management literature but remains insufficient, as the word "quality" seem to be more dominant in the production of goods; and the service sector. The studies of (Hoxley, 2000, pp. 527-540; Love, Smith, Treloar, \& Li, 2000, pp. 191-201; Tabish \& Kumar, 2011, pp. 809-823) remain significant based on the background of the research problem earlier stated, and they respectively investigated whether quality management systems was a determining factor when evaluating project tenders; while (KimWanSiu, Bridge, \& Skitmore, 2001) assessed the service quality of building maintenance providers from a maintenance service perspective.

The definition of quality as stated by Hellard (1995) from the construction project perspective justifies the rationale of this study. According to Hellard (1995), Until total quality of the end project, the building or structure, is delivered to its owner/sponsor (meaning functional and aesthetic requirements fulfilled within approved cost and time) the whole quality movement, quality inspection (QI), quality control $(Q C)$, quality assurance (QA), Total Quality Management (TQM), or whatever, means nothing and adds no real value to the construction industry's purpose. Quality can be achieved based on the completeness of quality in project and product life cycle with zero defects (Crosby, 1994), though Crosby seems to be referring to the production sector; however, quality management principles and tools are also critical requirements in modern project management practice (Asford, 2000; Barber et al., 2000, pp. 479-492; Joaquin, Hernandez, \& Aspinwall, 2008, pp. 1013-1028) this is aimed at integrating concisely the variability in projects relative to the dynamics of various stakeholders' interest (Gray \& Larson, 2000) as the lack thereof tantamount frequent specification variations (Aiyetan, 2014, pp. 755-769) and rework is thus accepted as an inevitable characteristics of the project processes. With regards to the objectives of this study, literature dealing with project management dynamics and identification, including quality management systems implementation in project life cycle, were further researched and presented.

\subsection{Project Management Dynamics and Identification}

The project management by nature is dynamic and varies significantly between projects (Gray \& Larson, 2000) thus requires the participation of interdisciplinary team to achieve the project objective (Gido \& Clement, 2003). Infrastructural construction activities would involve time, conceptualising, designing, managing, funding, organising and coordinating project requirements, which must be harmonised in the most efficient manner that will facilitate the completion of projects on schedule, and within estimated budget (Love, 2002, pp. 138-146); in accordance to the quality requirement and performance. Project identification usually require an understanding of client expectations, objectives of project and the project specifications (White \& Fortune, 2002, pp. 1-11; Wirick, 2009; Zhang, 2005, pp. 3-14) thereafter contractors must work to meet these expectations; thus must consider the strategic and operational alignment of projects (Larson, 1995, pp. 30-35; Li, Cheng, Love, \& Irani, 2001, pp. 171-179). Strategic alignment implies that the potential project will contribute more than competing alternatives to the organisation's strategic objectives such as market leadership through product or service differentiation (Milosevic \& Srivannaboon, 2006; Lam, Chua, Loh, \& Jaselskis, 1999, pp. 351-359; Larson, 1995, pp. 30-35); Operational alignment on the other hand means that customer needs and wants, remains the principal priority throughout the project life cycle (Kerzner, 2013). It further implies that salient issues such as trade-offs of scope, cost and schedule should be openly discussed and resolved by stakeholders (Jugdev \& Muller, 2005, pp. 19-31). Therefore any failure to actualise the strategic and operational alignment will most times result in project risk increase and decline in project quality (Cooke-Davies, Crawford, \& Lechler, 2009, pp. 110-123).

\subsection{Quality Management Systems Implementation in Project Life Cycle}

Quality management when considering project management is the process that ensures that all project activities necessary to design, plan and implement a project are effective (Kloppenborg \& Petrick, 2004, pp. 63-68; Thorpe \& Sunner, 2005; Holt \& Rowe, 2000, pp. 541-553) and project efficiency with regards to the objective and performance of the project was articulated (Husin, Adnan, \& Jusoff, 2008, pp. 41-47). Project quality management (PQM) is not an isolated, independent process (Jha \& Iyer, 2006, pp. 1155-1170) that occurs at the end of an activity to measure the level of quality of the output (Ogwueleka, 2011; Leonard, 2008, pp. 101-110). Quality management seeks to prevent and avoid than measuring and fixing poor quality outputs (Ogwueleka \& Mendie, 2014, pp. 826-843) and must be an integral part of every project management processes from the moment the project is initiated to the final stages involving project completion and commissioning (PMI, 2000; PMBOK, 2012; Tang, Qiang, Duffield, Young, \& Lu, 2009, pp. 129-141). All these studies provide greater insight into specific applications and benefits of quality management standards in project management, thus 
significantly resonate into theoretical findings that were harnessed in this study. The entire literature review serves to advance the debate about integrating quality management in nominated vendor systems (NVS) in oil and gas host community projects.

\section{Research Methodology}

This study was conducted in Rivers State, Nigeria, on the grounds that the local vendors are either based in Egi Kingdom or have their offices located in Rivers state. Data for the study were collected through interviews and distribution of two hundred and twenty-two (222) questionnaire which were administered by means of random sampling comprising contractors of various categories in the area under research. The choice of the respondents was on the basis that they were involved throughout the various stages of contracts and registered as contractors with TEPNG, therefore are most suitable to providing insight into quality management of contract execution in Egi host communities in Rivers State. The first section of the questionnaire consisted of demographics of the respondents, including company registration profile (Table 2), and Figure 3 provided the types of companies; quality standards and statutory certification of the companies was presented in (Table 3); while (Table 4) gave an insight on types of contracts executed. The second section focused on the primary objectives of the study; project quality management statements that have direct impact on project quality and reliability were extrapolated from ISO 9001 family of standards and rated based on the level of awareness, implementation and compliance of quality management systems. The data collected were analysed using statistical package for social sciences (SPSS) software version 22 to provide descriptive statistics. The hypothesis were tested using Goodness-of-fit-test and a summarised computation of the test results are shown in (Table 5). A goodness-of-fit-test is a statistical test that usually describes how well response variables fits into various set of observations and assumptions (Yuan, 2005, pp. 115-148; Maydeu \& Joe, 2006, pp. 713-732) and the test summarises the discrepancy between observed values and the values expected under a statistical model with known sampling distributions (MacCallum, Browne, \& Cai, 2006, pp. 19-35). 


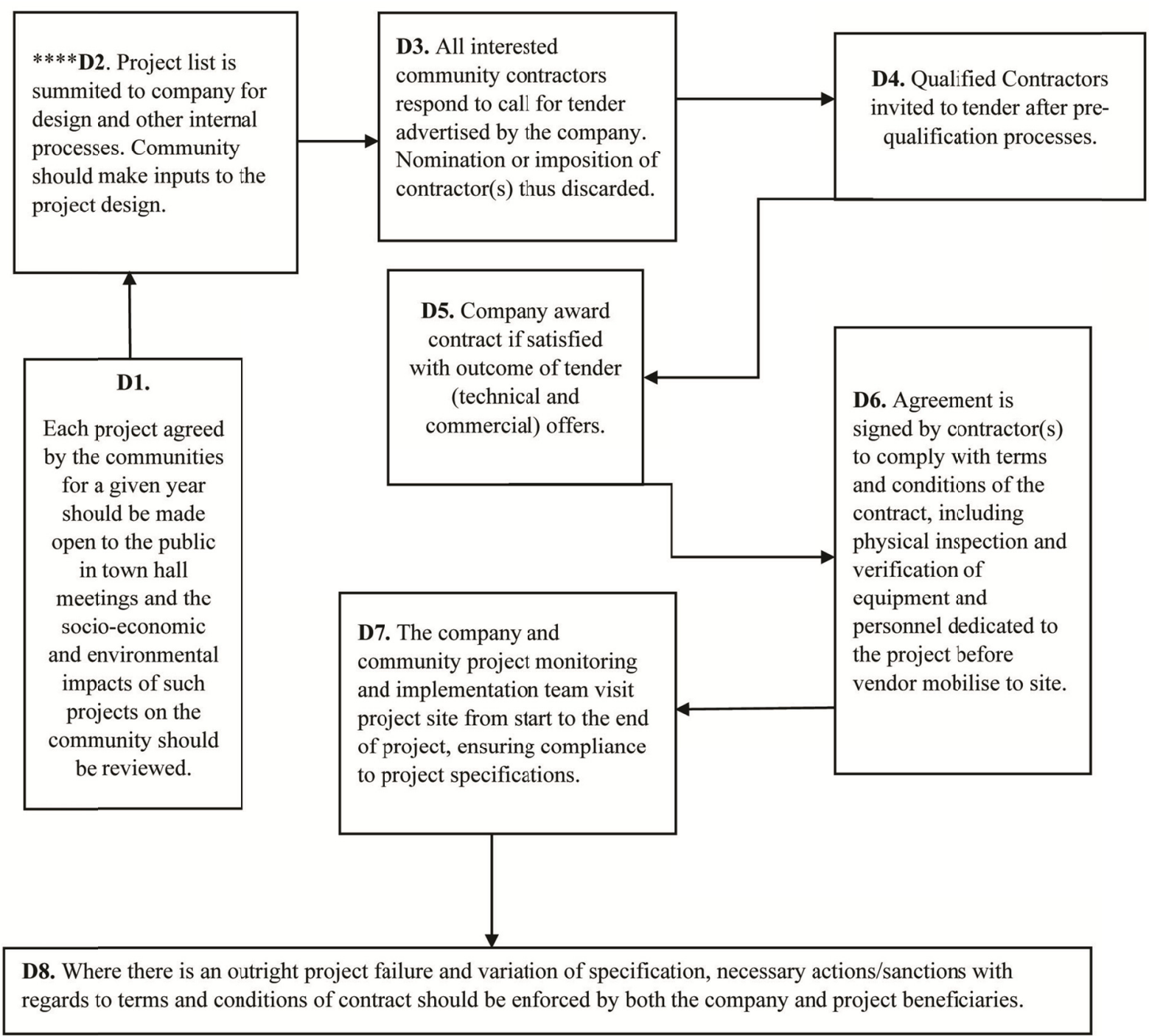

Figure 2. Nominated vendor system (NVS) project quality management model. Source: Author's conceptual framework

Note. $* * *$ The former process (A6 in figure 1) was that community leadership submit list of project and not be involved in the project design and whatever project design the company provides is acceptable, the major interest is who gets tender and wins the contract that are mostly driven by the epistemology of prebendalism. Even in isolated cases where some individual are privy to such project designs, there has not been any known case available to the author where a community ask collectively in a town hall meeting to see or possibly review the project design of their respective communities before sharing the "purchase order" or respond to call for tender. Therefore D8 encourages community participation inter alia in making inputs and reviewing of project design before call for tender.

\section{Findings}

Table 2. Company registration profile

\begin{tabular}{lll}
\hline Company Registration type & Frequency & Percentage \\
\hline Closed corporation sole proprietor & 145 & 65.32 \\
Limited Liability & 33 & 14.86 \\
Others & 44 & 19.82 \\
Total & $\mathbf{2 2 2}$ & $\mathbf{1 0 0}$ \\
\hline
\end{tabular}

Source: Author's field survey 2015. 


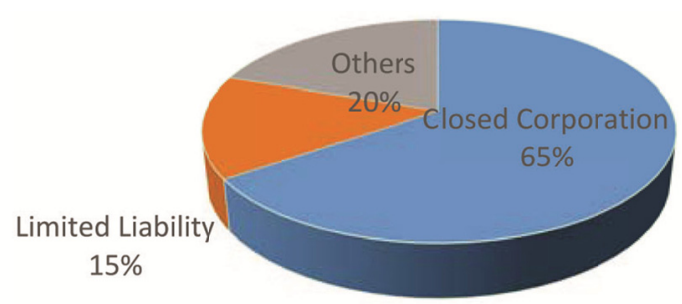

Figure 3. Types of companies in Egi host communities

Source: Author's field survey 2015.

Table 3. Number of times the word quality management appeared in company profile of respondents

\begin{tabular}{lll}
\hline Quality word in company profile booklet & Frequency & Percentages \\
\hline ISO:9000 Quality Management Systems (QMS) & 1 & 0.45 \\
Total Quality Management (TQM) & 1 & 0.45 \\
Others & 2 & 0.90 \\
None & 218 & 98.19 \\
Total & 222 & $\mathbf{1 0 0}$ \\
\hline
\end{tabular}

Source: Author's field survey 2015.

Table 4. Types of contract executed

\begin{tabular}{lll}
\hline Projects executed & Contractors & Percentages \\
\hline Procurement & 3 & 1.35 \\
Maintenance & 7 & 3.15 \\
General contract & 212 & 95.40 \\
Total & 222 & 100 \\
\hline
\end{tabular}

Source: Author's field survey 2015.

Table 5. A summarised computation of contractors' Goodness-of-fit test

\begin{tabular}{llll}
\hline Company Type & \multicolumn{2}{l}{ QMS; Compliance and Implementation (Goodness-of-fit test). } & Total \\
& Yes & No & 33 \\
Limited Liability & $E_{1,1}=14(9.51)$ & $E_{1,2}=19(23.49)$ & 44 \\
Others & $E_{2,1}=17(12.68)$ & $E_{2,2}=27(31.32)$ & 145 \\
Closed Corporation & $E_{3,1}=33(41.80)$ & $E_{3,2}=112(103.19)$ & $\mathbf{2 2 2}$ \\
Total & $\mathbf{6 4}$ & $\mathbf{1 5 8}$ & \\
\hline
\end{tabular}

Source: Author's field survey 2015.

$X^{2}=2.12+0.86+1.47+0.59+1.85+0.75=7.64$

$X_{0}^{2}=5.991$

$\mathrm{DF}=2 ; \alpha=0.05$

\section{Test hypothesis}

$\mathrm{H}_{0}$ : There are compliance of quality management systems in project execution among contractors in Egi host communities.

$\mathrm{H}_{\mathrm{a}}$ : There are non-compliance of quality management systems in project execution among contractors in Egi host communities.

\section{Discussion}

Since the chi-square test $X^{2}=7.64$ lies in the rejection region, the null hypothesis is therefore rejected; this implies that there is sufficient statistical evidence to accept the alternative hypothesis which states that there are non-compliance of quality management systems in project execution among contractors in Egi host communities. When the project management trends in the area under research were investigated, it became obvious that 
integrating quality culture in project management will increase the performance, excellence and competitiveness of contractors; however, the combined leverage of quality and project management is most times under-utilised partly due to inadequate experience in both fields, scheduling challenges and administrative constraints. In the study 145 contractors are registered as closed corporation (sole proprietor), this indicate that most business representing $65 \%$ are run by an individual, quality manual and clearly articulated quality policy were not found in the profile reviewed; 33 contractors representing $20 \%$ are limited liability companies with directors, however some companies in this set also follow the same trend as the closed corporation with regards to quality manual; while $15 \%$ representing other categories are individuals that are doing businesses in the area under research but uses their personal names or executing contracts as sub-contractors. Generally, there is a strong entrepreneurial drive amongst locals in the area under research, as $95 \%$ of the local vendor were involved in general contracts, which also implies that they are adjudged to meeting the minimum required competence to execute varying job scope ranging from inter alia mechanical, electrical, and civil engineering projects; which in the author's view could be greatly optimised when the broader spectrum of quality management systems becomes their organisational culture.

\section{Conclusion and Recommendations}

This study provides empirical findings emanating from local vendor understanding, compliance and implementation of quality management systems in community projects. It also provided an insight for development and identification of best practices in project execution in oil and gas host communities. Such best practice guidelines presented in this paper should eventually lead to project quality framework and operating procedures for infrastructural projects contract awards in host communities. Ensuring project quality plays an important role in economic and social development of people; as it provides the most basic infrastructure that promotes economic activities. Construction projects and contracts generally is a key provider of employment in both short, medium and long term and particularly in oil and gas host communities, therefore the incorporation of quality management systems is paramount for sustainable development. Project success must be accomplished without cost overrun and contractors quality management principles has a significant role to play in the outcome of any project (Boynton \& Zmud, 1984, pp. 17-27; Nguyen, Ogunlana, \& Lan, 2004, pp. 404-413). Contractors in host communities should appreciate the importance of quality and what it entails in the project life cycle, including the expectations of the project donors. Particularly, outlining what the quality standards of the contracting companies are, with regards to the project specification (Toor \& Ogunlana, 2009, pp. 149-167).

Quality planning: There should be quality manual and a clearly defined quality policy for every vendor seeking to have a competitive advantage. The quality policy of the various vendor can follow the widely recognised quality standards like the ISO 9000 family of standards or Total Quality Management (TQM), or it may have its tailored approach that meet the quest for quality (Terziovski, Samson, \& Dow, 1997, pp. 1-18; owell, 1995, pp. 15-37; Oakland, 2003; Kerzner, 2013). The quality policy of companies serves as a guide to the project implementation (Dale, Van Der Wiele, \& Van Iwaarden, 2013) and ensures that the management of the project and the output of the project are consistent with the quality framework (Jung \& Wang, 2006, pp. 716-22). The planning processes must include that the person responsible for the coordination of the project understands and able to identify the planning requirements, determine how these requirements can be achieved, including the costs and time demands to meet the identified requirements (PMBOK, 2012; Orwig \& Brennan, 2000, pp. 351-363).

A fundamental principle of project quality management is that quality is planned into the project, not inspected through (PMBOK, 2012) because planning for quality is considered cost-effective while inspecting work results in rework and rectifying other variations to conform to quality standards increases project cost (Rose, 2005). Every vendor should always bear in mind the cost of achieving the expected level of quality against the cost of non-conformance; as the cost of non-conformance can be more than the cost of quality, which include amongst others, loss of client, rework, and waste of materials. Quality cost usually includes safety measures, training and various processes that are in place to prevent poor quality. As nomination of contractors for projects has been entrenched and normalised in oil and gas host communities under research, the author argues that by integrating project quality management systems in agreements and MOU's as part of a service orientation and commitments, not only will projects quality be improved for sustainable development but the local vendors in Egi kingdom will also be better positioned to competing favourably for projects and services beyond their immediate communities because they would have set a benchmark that other community contractors in Niger Delta would strive to achieve.

Limitations and suggestions for future research: Conducting a field research in location such as the Niger Delta comes with extraordinary challenges. The challenges would inter alia be security and suspicion by locals 
that the researcher(s) has been sponsored to conduct study, including the unwillingness of the participants to engage in studies that are self-sponsored like this type of study because it is very unusual. Generally, the locals are more interested in participating in survey that are promoted by multinational oil companies (MNOC), international donor organisations and the government. The unwillingness of the MNOC workers to participant in the study for fear of losing their jobs is understandable, however, it also remains interesting even when findings and recommendation seeks to improve the project quality management status quo of their host communities, thus the study took longer than the author had anticipated due to these challenges. Against these backdrop, future research should look at studying the rational for the outlaw of tender processes and project failure tolerance by host communities, particularly in Obite community that regularly receive funding for a failed guest house project that is situated along Egita Road; and the company's interest in the continues funding of such project is also worth researching for the interest of sustainable development. The quality standards that are used by project donors to evaluate vendors in contract awards in host communities, including criteria for monitoring, evaluation and implementation of agreements and $\mathrm{MOU}(\mathrm{s})$ should also be subject of interest for future research. Nonetheless, this study is contextual, therefore the results and findings presented cannot in any way be generalised.

\section{Significance of the study}

There are currently lack of empirical research that investigated the link between quality management implementation and improvement of project management performance in the Niger Delta oil and gas host communities. Most literature on Niger Delta are concerned with political issues, insecurity, environmental pollution, human rights violation and other similar challenges that make headlines and those that attract international attention. However, in the mist of these challenges that has engulfed the region, the Niger Delta people continue to make giant strides in various endeavours such as entrepreneurship and there are also infrastructural and human capital development projects going on in various oil and gas host communities. This study explored project quality management and identified that some local vendors in the area researched are involved in various community projects but they have to incorporate quality management systems in order to ensure project quality, reliability and sustainable development. This research stands out as it brings a different perspective to project management in the Niger Delta and further proffers a nominated vendor system (NVS) project quality model for policy makers in the implementation of project agreements and MOU's in the oil and gas host communities studied.

\section{Acknowledgement}

The author would like to thank all the respondents for their time and wiliness to share their company profile. Editor's comments and those from the anonymous reviewers are highly appreciated and will assist the author in future research work.

\section{References}

Ahmed, S., Aoieon, R., Tang, S., \& Zheng, D. (2005). A comparison of quality management systems in the construction industries of Hong Kong and the USA. The International Journal of Quality and Reliability Management, 22(2/3), 149-161. https://doi.org/10.1108/02656710510577215

Aiyetan, O. (2014). Rework cost on building projects in the South Western part of Nigeria. Journal of Construction Project Management and Innovation, 4(1), 755-769.

Andrew, W., \& Lau-Tang, S. L. (2009). A survey on the advancement of QA (quality assurance) and TQM (total quality management) for construction contractors in Hong Kong. International Journal of Quality and Reliability Management, 26(5), 410-425. https://doi.org/10.1108/02656710910956166

Arditi, D., Elhassan, A., \& Toklu, Y. (2002). Constructability Analysis in the Design firm. Journal of Construction Engineering and 117-126. https://doi.org/10.1061/(ASCE)0733-9364(2002)128:2(117)

Asford, J. (2000). The management of quality in construction. London: E\&F Spon.

Barber, P., Graves, A., Hall, M., Sheath, D., \& Tomkins, C. (2000). Quality failure costs in civil engineering. International Journal of Quality and Reliability Management, 17(4), 479-492. https://doi.org/10.1108/02656710010298544

Boynton, A., \& Zmud, W. (1984). An assessment of critical success factors. MIT Sloan Management Review, 25(4), 17-27. 
Connor, J. T., \& Tucker, R. L. (1986). Industrial project constructability improvement. Journal of Construction Engineering and Management, 127(4), 281-290.

Cooke-Davies, T. J., Crawford, L. H., \& Lechler, T. G. (2009). Project management systems: Moving project management from an operational to a strategic discipline. Project Management Journal, 40(1), 110-123. https://doi.org/10.1002/pmj.20106

Crosby, P. (1994). Completeness: Quality for the 21st century. NY: Plume.

Dale, B. G., Van Der Wiele, T., \& Van Iwaarden, J. (2013). Managing quality. New York: John Wiley \& Sons.

Gido, J., \& Clement, J. (2003). Successful project management mason. OH: Thomson S.W.

Gray, C., \& Larson, E. (2000). Project Management: The managerial process. NY: Irwin McGraw-Hill.

Hellard, R. (1995). Project Partnering: Principle and Practice (p. 32). London: Thomas Telford. https://doi.org/10.1680/pppap.20436

Hiyassat, M. (2000). Applying the ISO standard to a construction company: A case study. International Journal of Project Management, 18, 275-280. https://doi.org/10.1016/S0263-7863(99)00051-4

Holm, M. (2000). Service quality and product quality in housing refurbishment. International Journal of Quality Management, 17(4/5), 527-540. https://doi.org/10.1108/02656710010298562

Holt, R., \& Rowe, D. (2000). Total quality, public management and critical leadership in civil construction projects. International Journal of Quality and Reliability Management, 17(4/5), 541-553. https://doi.org/10.1108/02656710010298571

Hoxley, M. (2000). Are construction fee tendering and professional construction service quality mutually exclusive. Construction Management and Economics, 18, 599-605. https://doi.org/10.1080/014461900407400

Husin, N., Adnan, H., \& Jusoff, K. (2008). Management of safety for quality construction. Journal of Sustainable Development, 1(30), 41-47. https://dx.doi.org/10.5539/jsd.vln3p41

IPENZ. (2008). Institution of Professional Engineers New Zealand Incorporated, (IPENZ): Practice notice 13. IPENZ.

Jergeas, G., \& Vander-Put, J. (2001). Benefits of constructability on construction projects. Journal of $\begin{array}{llll}\text { Construction Engineering } & \text { 281-290. }\end{array}$ https://doi.org/10.1061/(ASCE)0733-9364(2001)127:4(281)

Jha, K., \& Iyer, K. (2006). Critical factors affecting Quality Performance in Construction Projects. Total Quality Management, 17(9), 1155-1170. https://dx.doi.org/10.1080/14783360600750444

Joaquin, D., Hernandez, D., \& Aspinwall, E. (2008). A framework for building quality into construction projects. Total Quality Management, 19(10), 1013-1028. https://dx.doi.org/10.1080/14783360802264061

Jugdev, K., \& Müller, R. (2005). A retrospective look at our evolving understanding of project success. Project Management Journal, 36(4), 19-31.

Jung, J. Y., \& Wang, Y. J. (2006). Relationship between total quality management (TQM) and continuous improvement of international project management (CIIPM). Technovation, 26(5), 716-722. https//doi.org/10.1016/j.technovation.2006.01.003

Kerzner, H. R. (2013). Project management: a systems approach to planning, scheduling, and controlling. New York: Wiley \& Sons.

KimWanSiu, G., Bridge, A., \& Skitmore, M. (2001). Assessing the service quality of building maintenance providers: mechanical and engineering services. Construction Management and Economics, 19, 719-726. https://dx.doi.org/10.1080/01446190110062104

Kloppenborg, T., \& Petrick, J. (2004). Mananging Project Quality. Quality Progress, 37(9), 63-68.

Lam, E., Chua, D., Loh, P., \& Jaselskis, E. (1999). Key determinants for construction schedule performance. $\begin{array}{llll}\text { International Journal of Project } & \text { Management, } & \text { 17(6), }\end{array}$ https://doi.org/10.1016/S0263-7863(98)00058-1

Larson, E. (1995). Project partnering: results of study of 280 construction projects. Journal of Management in Engineering, 11(2), 30-35. https://doi.org/10.1061/(ASCE)0742-597X(1995)11:2(30) 
Leonard, D. (2008). Quality management practices in the US homebuilding industry. Journal of Total Quality Management, 22(10), 101-110. https://dx.doi.org/10.1108/17542731011009658

Li, H., Cheng, E., Love, P., \& Irani, Z. (2001). Co-operative benchmarking: a tool for partnering excellence in construction. International Journal of Project Management, 19, 171-179. https://doi.org/10.1016/S0263-7863(99)00033-2

Love, P. (2002). Auditing the indirect consequences of rework in construction; A case based approach. Managerial Auditing Journal, 17(3), 138-146. https://doi.org/10.1108/02686900210419921

Love, P., Smith, J., Treloar, G., \& Li, H. (2000). Some empirical observations of service quality in construction. Engineering Construction and Architectural Management, 7(2), 191-201. https://doi.org/10.1108/eb021144

Low, S., \& Teo, J. (2004). Implementing total quality management in construction firms. Journal of Management in Engineering, 20(1), 8-15. https://doi.org/10.1061/(ASCE)0742-597X(2004)20:1(8)

MacCallum, R., Browne, M., \& Cai, L. (2006). Testing differences between nested covariance structure models: Power analysis and null hypotheses. Psychological Methods, 11, 19-35. https://doi.org/10.1037/1082-989X.11.1.19

Maydeu, O., \& Joe, H. (2006). Limited information goodness-of-fit-testing in multidimensional contigency tables. Psychometrika, 71, 713-732. https://doi.org/10.1007/s11336-005-1295-9

Miloševic, D., \& Srivannaboon, S. (2006). A theoretical framework for aligning project management with business strategy. NY: PMI.

Nguyen, L., Ogunlana, S., \& Lan, D. (2004). A study on project success factors in large construction projects in Vietnam. Engineering, Construction and Architectural Management, 11(6), 404-413. https://doi.org/10.1108/09699980410570166

Oakland, J. S. (2003). Total quality management: text with cases. London, New York: Routledge.

Ogwueleka, A. (2011). The critical success factors influencing project performnace in Nigeria. International Journal of Management Science and Engineering Management, 6(5), 343-349.

Ogwueleka, C., \& Mendie, E. (2014). Evaluation of safety and quality management in construction projects; A study of Ibom tropicana construction projects. Journal of Construction Project Management and Innovation, 4(1), 826-843. Retrieved from https://hdl.handle.net/10520/EJC154993

Orwig, R. A., \& Brennan, L. L. (2000). An integrated view of projects and quality management for project-based organizations. International Journal of Quality \& Reliability Management, 17, 351-363. https://doi.org/10.1108/02656710010298382

Othman, A. A. (2011). Constructability for reducing construction waste and improving building. Built Environment Journal, 8(2), 31-54.

owell, T. C. (1995). Total quality management as competitive advantage: a review and empirical study. Strategic Management Journal, 16(1), 15-37.

PMBOK. (2012). A Guide to the project management Body of Knowledge. New York: Project Management Institute.

PMI. (2000). Standard Committee: A guide to the project management body of knowledge (PMBOK Guide). Project Management Institute.

Pocock, J. B., Kuennen, S. T., Gambatese, J., \& Rauschkolb, J. (2006). Constructability state of practice report. Journal of Construction Engineering and Management, 132(4), 373-383. https://doi.org/10.1061/(ASCE)0733-9364(2006)132:4(373)

Radosavljevic, M., \& Bennett, J. (2012). Construction management strategies: A theory of construction management. London: Wiley-Blackwell.

Rose, K.H. (2005). Project quality management: why, what and how. Fort Lauderdale, Florida: J. Ross Publishing.

Saghatforoush, E., Hasim, S., Jaafar, M., \& Abdul-Kadir, M. (2009). Constructability implementation among Malaysian building contractors. European Journal of Scientific Research, 29(4), 518-532.

Tabish, S., \& Kumar, N. (2011). Identification and evaluation of success factors for public construction projects. Construction Management and Economics, 29, 809-823. https://dx.doi.org/10.1080/01446193.2011.611152 
Tang, S., Ahmed, S., Aoieong, R., \& Poon, S. (2005). Construction Quality Management. Hong Kong: Hong Kong University Press.

Tang, S., Poon, S., Ahmed, S., \& Wong, F. (2003). Modern Construction Project Management. Hong Kong: Hong Kong University Press.

Tang, W., Qiang, M., Duffield, C., Young, D., \& Lu, A. (2009). Enhancing total quality management by partnering in construction. Journal of Professional Issues in Engineering Education and Practice, 135(4), 129-141. https://doi.org/10.1061/(ASCE)1052-3928(2009)135:4(129)

TEPNG, \& Landlord. (2012). Agreement between Total E\&P Nigeria Limited and Egi Oil \& Gas landlord families and host communities (pp. 1-26). Port Harcourt.

Terziovski, M., Samson, D., \& Dow, D. (1997). The business value of quality management systems certification. Evidence from Australia and New Zealand. Journal of Operations Management, 15(1), 1-18. https://doi.org/10.1016/S0272-6963(96)00103-9

Thorpe, B., \& Sunner, P. (2005). Quality management in construction. Structural Survey, 23(2/3), 237.

Toor, S., \& Ogunlana, S. (2009). Construction professionals perception of critical success factors for large scale construction projects. Construction Innovation: Information, Process Management, 9(2), 149-167.

Trigunarsyah, B. (2004). A review of current practice in constructability improvement: case studies on construction projects in Indonesia. Journal of Construction Management and Economics, 22, 567-580. https://doi.org/10.1080/0144619042000202870

White, D., \& Fortune, J. (2002). Current practice in project management: an empirical evidence. International Journal of Project Management, 20(1), 1-11. https://doi.org/10.1016/S0263-7863(00)00029-6

Wirick, D. (2009). Public-sector project management. NJ: Wiley and Sons. https://doi.org/10.1002/9780470549131

Xiao, H., \& Proverb, D. (2002). The performance of contractors in Japan, the UK and the USA: an evaluation of construction quality. International Journal of Quality and Reliability, 19(6), 672-687. https://doi.org/10.1108/02656710210429564

Yuan, K. (2005). Fit indices versus test statistics multivariate. Behavioral Research, 40, 115-148.

Zhang, X. (2005). Critical success factors for public-private partnerships in infrastructure development. Journal of Construction Management, 131(1), 3-14. https://doi.org/10.1061/(ASCE)0733-9364(2005)131:1(3)

\section{Copyrights}

Copyright for this article is retained by the author(s), with first publication rights granted to the journal.

This is an open-access article distributed under the terms and conditions of the Creative Commons Attribution license (http://creativecommons.org/licenses/by/4.0/). 